\title{
Taxonomy and palaeoecology of Cretaceous nautilids Angulithes galea (Fritsch in Fritsch \& Schlönbach, 1872) and Angulithes westphalicus (Schlüter, 1872)
}

\author{
JIŘÍ FRANK
}

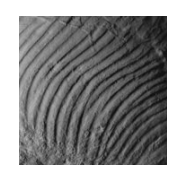

\begin{abstract}
Angulithes galea (Fritsch in Fritsch \& Schlönbach, 1872) and Angulithes westphalicus (Schlüter, 1872) are representatives of Angulithes Montfort, 1808, occurring in the Late Cretaceous of Europe, from the Late Turonian to the Late Campanian. Following examination of the majority of specimens representing these species and their specific morphology, a detailed revision was made. Both species undergo significant morphological changes during their ontogeny, changing the shape of the ventral side and whorl cross-section attended by onset and loss of ventral keel and changing of the shell surface (by A. galea). Comparing these changes with the ontogeny of recent Nautilus suggests they are expressions of the approach and attainment of maturity. Due to this comparison, comparable changes in other taxa can be similarly interpreted, e.g. representatives of the genus Deltocymatoceras. The changes undergone by A. galea are at maturity accompanied by additional features such as strong radial ribbing, which is comparable with the ribbing in Deltocymatoceras. The affinity (ventral keel, suture, ontogeny and stratigraphy) of this genus with Angulithes is a topic for discussion. - Key words: Angulithes, nautilids, Late Cretaceous, taxonomy, palaeoecology, ontogeny.
\end{abstract}

FRANK, J. 2010. Taxonomy and palaeoecology of Cretaceous nautilids Angulithes galea (Fritsch in Fritsch \& Schlönbach, 1872) and Angulithes westphalicus (Schlüter, 1872). Bulletin of Geosciences 85(3), $487-496$ (5 figures, 2 electronical appendices). Czech Geological Survey, Prague. ISSN 1214-1119. Manuscript received April 6, 2010; accepted in revised form July 19, 2010; published online September 13, 2010; issued September 30, 2010.

Jiři Frank, Institute of Geology and Palaeontology, Faculty of Science, Charles University, Albertov 6, Praha 2, 128 43, Czech Republic; frank@natur.cuni.cz.

Studies of morphological changes in nautilids (e.g. Wani \& Ayyasami 2009) during ontogeny greatly assist in other areas of study such as taxonomy (most important in Cretaceous nautilids, e.g. Hyatt 1884, Kummel 1956, Wiedmann 1960, Shimansky 1975), phylogeny (e.g. Dzik 1984, Engeser 1999), palaeoecology (e.g. Tintant \& Kabamba 1985) and taphonomy (e.g. Wani 2004, 2007). In comparison with ammonoids (Ward 1980) and with respect to the relative conservativeness of the morphology of nautilid shells, studies of any morphological changes are very valuable. This conservativeness has been interpreted, mostly in post-Triassic nautiloids, as a response to their palaeoecology (Tintant \& Kabamba 1985), unlike the relatively diversified ammonoids which occupied various niches (Ward 1980).

One of the first studies utilising morphometric analysis of intra-specific variation and ontogenetic changes in shell morphology (Wani \& Ayyasami 2009) focused on the species Eutrephoceras clementinum (d'Orbigny, 1840) from the Cretaceous of the Ariyalur district, southern India. This study required a large number of well-preserved specimens, preferably from the same locality and horizon (see also Kummel 1956). The conditions for the study presented here are less favourable. However, the studied specimens show very conspicuous morphological changes during their ontogeny which can be interpreted without morphometric analyses. This study is focused on interpretation of morphological changes during ontogeny in the Late Cretaceous species Angulithes galea and A. westphalicus.

\section{Material}

The studied material comprised 25 specimens of Angulithes galea, 26 specimens of A. westphalicus and 3 specimens of Deltocymatoceras for comparison (for details see online Appendices 1, 2, www.geology.cz/bulletin). The specimens come from the following institutions (with abbreviations in brackets): The National Museum, Prague (NM), Museum of Eastern Bohemia, Hradec Králové (MHK), The "Orlické Muzeum", Choceň (OM), The "Polabské Muzeum”, Poděbrady, Nymburk (PMP, PMN), The Museum of the Bohemian Paradise, Turnov (MT), The Regional Museum, Teplice (RMT) and the personal collection of Mr. Boštík, Horní Újezd u Litomyšle (PCB), Czech 


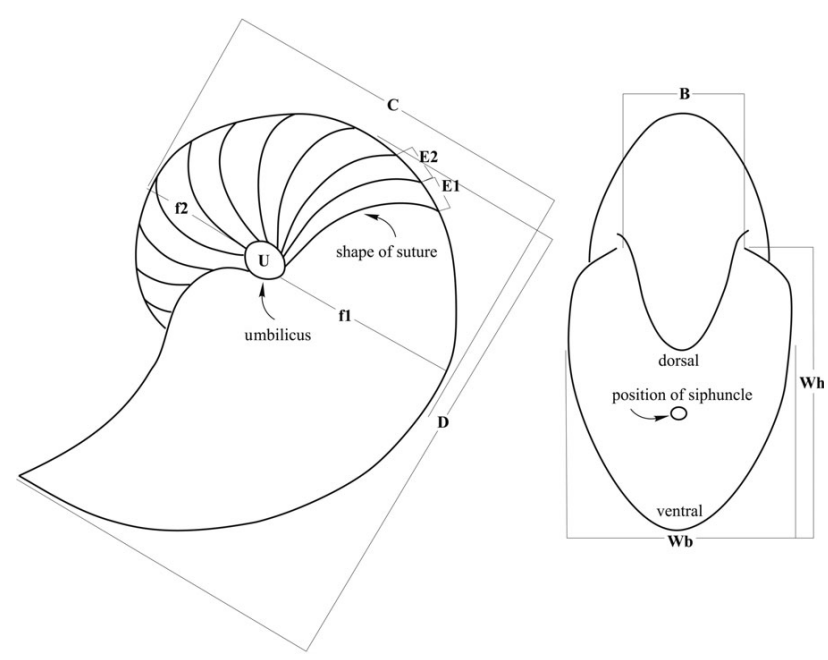

Figure 1. Criteria and measurements used for taxonomic classification of nautilids.

Republic; The Natural History Museum, London (NHM), England; Museum für Naturkunde, Berlin (MB), Goldfuß Museum, Bonn (GMB); Ruhr Museum, Essen (RE), Germany; and Das Naturhistorische Museum, Wien (NMW), Austria. The available specimens are often deformed or incomplete. However, several large specimens are very well preserved. Juveniles are very often poorly preserved and their determination is very complicated.

The following shell parameters were measured (Fig. 1): $\mathrm{D}=$ maximum diameter $\mathrm{Wb}=$ maximum width of last whorl; $\mathrm{Wh}=$ maximum height of last whorl; $\mathrm{C}=$ maximum height of shell ( $\mathrm{f} 1, \mathrm{f} 2=$ height of the whorl from the umbilicus); $\mathrm{B}=$ width of the shell at the umbilicus; $\mathrm{E}=$ distance between septa on the ventral side (all values in $\mathrm{mm}$ ); ratios are $\mathrm{Wb} / \mathrm{D}, \mathrm{Wh} / \mathrm{D}$ and $\mathrm{Wb} / \mathrm{Wh}$. The most important features for taxonomic analyses are: the position of the siphuncle; the suture pattern; general form of the shell and the whorl crosssection; the character of the umbilicus, and the surface ornamentation of the shell. For orientation see Fig. 1 (detailed morphological features and terms as in Teichert 1964).

\section{Systematic palaeontology}

Subclass Nautiloidea Agassiz, 1847

Order Nautilida Agassiz, 1847

Family Nautilidae Blainville, 1825

\section{Genus Angulithes Montfort, 1808}

Type species. - Angulithes triangularis Montfort, 1808.

Diagnosis. - Nautiliconic, generally compressed, rather involute, with strongly convergent and slightly convex whorl sides. Whorls with narrowly rounded to sharply angular ventral side and generally, deeply impressed dorsal zone. Suture moderately sinuous with narrowly rounded to pointed ventral saddle, a broad shallow or deep lateral lobe, rounded saddle on the inner lateral side and small lobe on the umbilical shoulder. Shell generally smooth, growth lines may be very pronounced. Siphuncle small, located dorsocentrally. The diagnosis is slightly modified from that of Montfort (1808), Kummel (1956) and Wilmsen (2000).

Remarks. - This study follows the suggestion (Kummel 1956, Wilmsen 2000) of the close relationship between $A n$ gulithes and Deltoidonautilus Spath, 1927 (for more details see also Wiedmann \& Schneider 1979, p. 653; Matsumoto 1983, p. 14 and Wilmsen 2000, p. 33) and also the opinion of Kummel (1956) who regarded Deltoidonautilus as synonymous with Angulithes.

Stratigraphic and geographic range. - The first occurrence of Angulithes (Angulithes arcuatus, Deshayes in Leymerie 1842) is from the Albian, Early Cretaceous of France and England. The youngest occurrence (Angulithes bakeri, Teichert 1947) is from the Oligocene of Australia. Most of the Late Cretaceous species are known from Europe, but also from southern India, Peru and Texas. Tertiary species of $A n$ gulithes are very widely distributed, being known from North and South America, Europe, Africa, Pakistan, and Australia. Most of the Tertiary species are Eocene in age.

Angulithes galea (Fritsch in Fritsch \& Schlönbach, 1872) Figures 2, 3J-N

1872 Nautilus galea Fr.; Fritsch \& Schlönbach, p. 23, pl. 12, fig. 3, pl. 15, figs 3,4 .

1872-75 Nautilus rugatus Fr. \& Schloenb. - Geinitz, pp. 181, 182, pl. II. 31, fig. 16.

non 1872-75 Nautilus sublaevigatus d'Orbigny. - Geinitz, pp. 182, 183, pl. II. 32, figs 1-3.

non 1876 Nautilus westphalicus Schlüt. - Schlüter, pp. 175, 176, pl. 48, figs 3-5.

1883 Nautilus galea Fr. \& Schl. - Frič, pp. 90, 91, text-fig. 51.

1885 Nautilus galea Fr. \& Schl. - Frič, p. 85, text-fig. 51.

1956 Angulithes galea Fritsch \& Schlönbach. - Kummel, p. 456.

1960 A. (Angulithes) galea Fritsch. - Wiedmann, pp. 192, 193, pl. 22, fig. K.

1975 Deltoidonautilus galea Fritsch \& Schlönbach. Shimansky, p. 137, tab. 3.

2003 Deltocymatoceras galea Fritsch \& Schlönbach. Ziegler, pp. 49, 58, 61.

2007a Deltocymatoceras galea Fritsch \& Schlönbach. Frank, pp. 12, 13, pl. 1, fig. 2. 
2007b Deltocymatoceras galea Fritsch \& Schlönbach. Frank, p. 35, pl. 1, fig. 2.

2009 Deltocymatoceras galea Fritsch \& Schlönbach. Frank, pp. 13, 14.

Lectotype. - NM O 3105. This specimen figured by Fritsch \& Schlönbach (1872) on pl. 12, fig. 3 is herein designated as the lectotype because it is the only preserved specimen from the original type collection (originally 3 specimens). The lectotype is deposited in the National Museum, Prague, Czech Republic.

Type locality. - Zámostí near Mladá Boleslav, Czech Republic.

Type horizon. - Trigonia Beds, Jizera Formation, Early Late Turonian, Subprionocyclus neptuni and Inoceramus perplexus zones.

Description. - Nautiliconic, involute, oval-shaped shell. Slightly depressed, obtusely sagittate whorl cross-section, with convex lateral sides. The maximum width of the whorl is on the inner lateral sides. From the penultimate to the last whorl there is a remarkable keel on the ventral side which is most conspicuous on the body chamber (Fig. 4A). The body chamber is large and elongated to $1 / 2$ of the whorl. The ventral keel of big specimens (diameter $\geq 250 \mathrm{~mm}$ ) is reduced in the apertural area; the crosssection of the whorl is moderately depressed with broadly rounded ventral and lateral sides (Fig. 4B). The maximum width is in the middle of the lateral sides. The suture is simple with a very small umbilical lobe, a remarkably narrow saddle on the umbilical margin and inner lateral side, a broad shallow lateral lobe and very shallow saddle on the ventral side. The surface of the shell is smooth, ornamented only with growth lines which are very noticeable on the last whorl. The course of the growth lines follows the shape of the aperture and adaperturally has an unusual sinus on the lateral sides. In the apertural area of large specimens, conspicuous radial ribbing appears. The ribs are very fine in the umbilical area where they originate, and follow the shape of the aperture across the lateral to the ventral side. The width of the ribs rapidly increases across the lateral to the ventral side where they can be up to $\geq 10 \mathrm{~mm}$ wide. Growth lines are also visible on the ribs. The ribs are irregularly spaced, sometimes bifurcating, more rarely trifurcating on the inner or middle lateral sides. In the area where the ribbing emerges, the ventral keel gradually diminishes. The last and sometimes also the penultimate phragmocone chamber behind the body chamber is in most cases distinctively narrower than the preceding chambers. The umbilicus is almost closed. The position of the siphuncle is dorso-central on several fragments of phragmocone chambers which most probably belong to this species.
Material. - The specimen of Angulithes galea NM O 3105 (Fig. 2A-C) is slightly deformed in the apertural area; however, the overall shape of its shell including the conspicuous ventral keel is well preserved. The suture is inconspicuous. Both specimens from the MHK collection (MHK P 672, Fig. 2D-F and MHK P 576) are very well preserved with complete body chamber and no deformation, well-preserved sutures, apertural ribbing and ventral keel. Specimen NM O 02359 (Fig. 2G, H) is slightly deformed askew, otherwise well preserved with remarkable sutures and complete body chamber with ventral keel and strong ribbing. In specimen PCB A01 (Fig. 2I, J) half of the whorl is covered by matrix. Juvenile specimen MT P 542 (Fig. 3J-L) shows the initial development of the ventral keel. Separated phragmocone chambers (RMT PA 1325/1, 2, Fig. 3M and MT P543, Fig. 3N) show the position of the siphuncle, but are slightly laterally deformed.

Discussion. - In juveniles with a shell size of up to several centimetres in diameter, the shell is slightly depressed and without a keel (Fig. 3J-L). The keel appears only on the penultimate whorl. Juveniles of Angulithes galea are until this point noticeably similar to those of Eutrephoceras Hyatt, 1894, particularly E. sublaevigatum (d'Orbigny 1840), and depending upon preservation, it is difficult to distinguish these species (Fritsch \& Schlönbach 1872; Frič 1883, 1885; Wiedmann 1960). There are no other significant characters until the formation of the keel, which does not appear in E. sublaevigatum. The suture of both species is very similar. However, E. sublaevigatum has a narrower umbilical saddle and the suture passes into a shallow lobe across the ventral side. The whorl of E. sublaevigatum is more depressed with widely rounded lateral sides, and it appears almost kidney-shaped in cross section.

Angulithes westphalicus (Schlüter, 1872) is closely allied, and most probably phylogenetically connected to A. galea due to its similarity and stratigraphic occurrence. Both species possess a conspicuous ventral keel. The whorl of A. westphalicus is slightly more compressed. The most noticeable difference is in the sutures: the suture of $A$. westphalicus begins in a shallow umbilical lobe and passes across the umbilical margin and the inner lateral side in a shallow, narrow and regularly rounded saddle, which is less conspicuous than the saddle of A. galea. The suture on the lateral side is almost straight with an inconspicuous shallow lobe. The suture crosses the ventral side in a shallow saddle. The ventral keel gradually decreases in the apertural area in both taxa. However, strong ribbing or other sculpture is absent in A. westphalicus.

Wiedmann (1960) compared Angulithes galea with Angulithes arcuatus (Deshayes in Leymerie, 1842) from the Albian of France and England. This species is similar to 
A. galea in its trigonal whorl cross-section and the remarkable keel. However, the previous whorl is deeply impressed and the lateral sides are less convex in A. arcuatus. Its siphuncle is central and the suture is unknown.

Surface sculpture are unusual in Angulithes, but may occur for instance in Angulithes vascogoticus (Wiedmann 1960) from the Late Cenomanian of Spain (Wilmsen 2000, p. 37). On the outer lateral sides and ventral side of the phragmocone this species shows strong undulation (ribbing) which is similar to that observed in Anglonautilus undulatus (Sowerby 1813), discussed in Wilmsen (2000, p. 36). However, it is completely different from the ribbing in A. galea which is found on the apertural area of the last whorl. Both species show remarkable morphological changes on the ventral side during their ontogeny: initially the ventral side develops a regularly rounded shape during early ontogenesis. In the next stage, it gradually forms a ventral keel, and in the fully mature shell (Wilmsen 2000), the venter is again regularly rounded on the body chamber (maximum diameter of fully "mature" specimens is 130-150 mm). A. galea has a similar course of ontogeny, but with the ventral keel being most prominent on the body chamber of fully grown specimens (maximum diameter 250-320 mm).

The majority of "keeled" species have a similarly shaped ventral side in the early ontogenetic stage, as for example the type species Angulithes triangularis (Montfort 1808). This species has a similar course of ontogeny, which was also noted by Foord (1891, p. 267): "the periphery can be alternately rounded and sharply angular". Nevertheless, this species differs significantly in its more compressed whorl cross-section and in the shape of the suture with a broad, deep lateral lobe and narrow ventral saddle.

Due to the strong apertural ribbing, Angulithes galea was several times classified as a Deltocymatoceras. The main distinguishing character of Deltocymatoceras is the combination of a strong ventral keel and strong radial ribbing on the whole shell (Kummel 1956). A. galea is similar to Deltocymatoceras rugatus (Fritsch \& Schlönbach 1872) in the suture, ventral keel and also in stratigraphic and geographic occurrence. D. rugatus has a more depressed whorl cross-section and the fully mature shell (maximum diameter 180-200 mm) is smaller than in A. galea. Both species have a similar course of ontogeny with morphological changes on the ventral side and the apertural ribbing of A. galea being comparable with the ribbing of $D$. rugatus which covers the whole shell. It is questionable as to whether or not the ribbing in A. galea has its origin in a common ancestry with $D$. rugatus. The precise relationship of these two morphologically overlapping, sympatric taxa has yet to be fully demonstrated. A. galea is assigned to Angulithes rather than Deltocymatoceras because the surface of the shell remains generally smooth during ontogeny and apertural ribbing is seen only in the fully grown shell.
Stratigraphic and geographic range. - From the lowest part of the Late Turonian (Fritsch \& Schlönbach 1872) Subprionocyclus neptuni and Inoceramus perplexus zones to the Early-Middle Coniacian (new distribution in this study) Volviceramus koeneni Zone (sensu Košták et al. 2004), Czech Republic (Fritsch \& Schlönbach 1872) and Germany (Geinitz 1872-1875 and new occurrence in this study).

\section{Angulithes westphalicus (Schlüter, 1872)}

Figure 3A-I

1872 Nautilus Westphalicus n. sp.; Schlüter, p. 13.

1876 Nautilus Westphalicus Schlüter. - Schlüter, p. 175, pl. 47, figs 1, 2 .

1956 A. westphalicus (Schlüter). - Kummel, p. 457, text-fig. 33/I.

1960 ?A. (Angulithes) westphalicus (Schlüter). - Wiedmann, p. 186, pl. 21, fig. O.

1975 N. westphalicus (Schlüter). - Schimanski, p. 136.

1999 Deltoidonautilus westphalicus (Schlüter). - Wittler, Roth \& Legant, p. 37, text-figs 51a/b, 52.

2000 Angulithes westphalicus (Schlüter). - Wilmsen, p. 37, pl. 3, fig. 1a/b; pl. 5, figs 6, 20 .

?2001 Angulithes cf. westphalicus (Schlüter). - Fözy, pp. 34-36, pl. 5 .

Lectotype. - GMB 97. This specimen subscribed and figured by Schlüter $(1872,1876)$ on pl. 47, figs 1,2 is designated in this study as lectotype because it is the only one known specimen marked as original type from the type collection. The specimen is deposited in the Goldfuß $\mathrm{Mu}-$ seum, Bonn, Germany.

Type locality. - Dülmen, Westphalia, Germany.

Type horizon. - "Quadraten-Kreide", Lower Campanian, Scaphites binodosus and Offaster pilula zones.

Description. - Nautiliconic, involute, oval, almost discoidal shell. Whorl cross-section appears slightly compressed due to the remarkable ventral keel. Lateral sides are convex and the maximum width of the whorl crosssection is in their inner part. The ventral keel appears on the penultimate and last whorl, and on the fully-grown shell $(\geq 250 \mathrm{~mm}$ ) it gradually decreases in the apertural area. The shell is slightly depressed in the early ontogenetic stage with a regularly rounded ventral side. The surface of the shell is smooth. The suture is slightly sinuous with a small shallow umbilical lobe, shallow, narrow and regularly rounded saddle on the umbilical margin and on the inner lateral side, with weak to almost straight lateral lobe, and a shallow saddle on the ventral side which can be accentuated by the ventral keel. The last phragmocone chamber is 


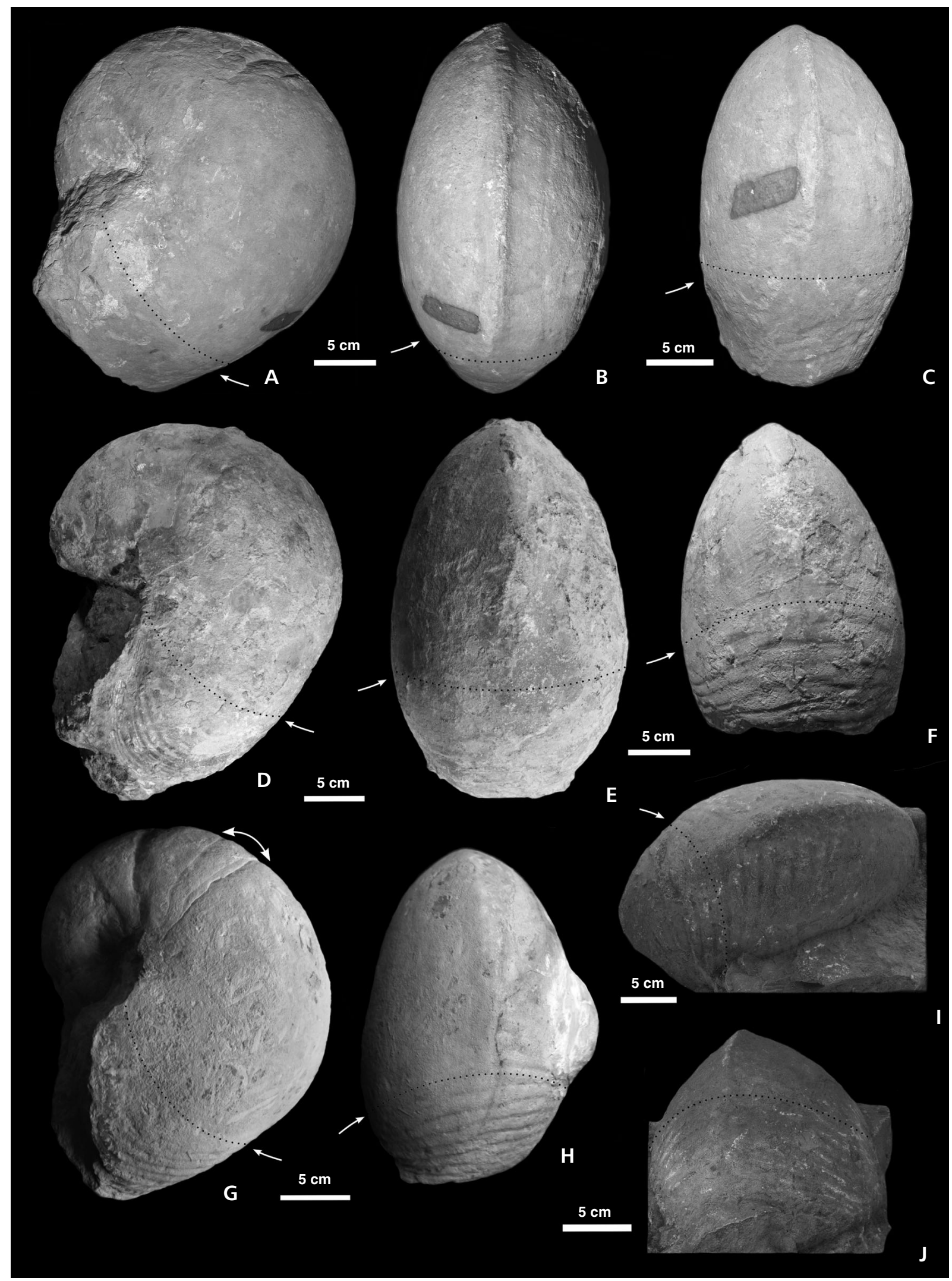

Figure 2. Adult specimens of Angulithes galea. • A-C - lectotype NM O 3105; D-F - specimen MHK 80005 P 672; G, H - specimen NM O 02359 ; $\mathrm{I}, \mathrm{J}$ - specimen PCB A 01. A dotted black line highlighted by arrows shows the forming of the apertural contraction. A white line with arrows shows the size of the last phragmocone chamber. 
noticeably narrower than the previous ones. The narrow umbilicus is open. The position of the siphuncle is unknown.

Material. - The specimen of Angulithes westphalicus (GMB 97, Fig. 3A-C) has an almost complete body chamber, with significant ventral keel and sutures. The surface of the body chamber of the large specimen RE A 4084 (Fig. 3D-F) is more poorly preserved. However, it is a complete specimen without deformation. The disappearance of the ventral keel on the body chamber is difficult to recognize due to the state of preservation. Juvenile specimen MB A23 (Fig. 3G-I) is dorso-ventrally deformed; nevertheless, it shows the onset of the ventral keel.

Discussion. - Angulithes westphalicus (as A. galea) lacks a ventral keel in the early ontogenetic stages (Fig. 3G-I). Juveniles are similar to Eutrephoceras (Wiedmann 1960) due to their simple suture and the shape of the shell and it is difficult to distinguish them from juveniles of Eutrephoceras darupense (Schlüter 1876). Both species occur in the same localities and horizons in Northern Germany and Spain (e.g. Wilmsen 2000). Nevertheless, they differ significantly in the late ontogenetic stage, in the shape of the whorl, in measurements of the shell and slightly in the suture. Wiedmann (1960, p. 186) mentioned that A. westphalicus is noticeably similar (especially in the suture) to Eutrephoceras. His hypothesis is that "this species is an example of convergent evolution to Angulithes, which proves that different shapes of a shell [body chamber] can cover the real relationship". It is obvious that the similarity of $A$. westphalicus and $A$. galea, especially in the early ontogenetic stage, point to a possible relationship with Eutrephoceras, but it could also be a consequence of adaptation to the same mode of life and environment at this ontogenetic stage.

Schlüter (1876) noted that Angulithes westphalicus could be identical to A. galea due to their similarity. He also mentioned that the difference between the narrowly open umbilicus of $A$. westphalicus and the almost closed umbilicus of A. galea cannot be proven because of differences in preservation and that the umbilicus of $A$. galea is probably identical. After detailed inspection of several specimens, the umbilicus of $A$. westphalicus was found to be a little more open than that of A. galea. Additionally, they differ in the more convex lateral sides of $A$. galea and the almost straight lateral suture of $A$. westphalicus. Moreover, A. westphalicus does not form any significant sculpture in the apertural area of the fully grown shell, unlike A. galea. The species also differ in their stratigraphic occurrence.

Angulithes fleuriausianus (d'Orbigny, 1840) is similar to A. westphalicus in its suture, with a shallow, narrow and regularly rounded saddle on the umbilical margin and inner lateral sides. However, the lateral lobe of A.fleuriausianus is deeper than that of $A$. westphalicus. The shape of the whorl cross-section of A. fleuriausianus is more compressed, and the ventral side is narrowly rounded without a keel throughout its ontogeny. Angulithes triangularis has a similar keel to $A$. westphalicus, but it differs significantly in the shape of the suture, possessing a distinctive lateral lobe. The species also differ considerably in their stratigraphic occurrence.

The specimen of Angulithes cf. westphalicus (with maximum diameter $206 \mathrm{~mm}$ ) described by Fözy (2001) from the Campanian of Sümeg, Hungary, has (according to the description on p. 34 and figure p. 35) a similar suture with conspicuous lateral lobe comparable to that of A. fleuriausianus or A. galea. Moreover, this species "lacks the weak angular sharpening of the venter and this was the main reason for using the open nomenclature". However, the ventral side is described as highly arched. Based on the information and the figure, it is highly probable that this species belongs to Angulithes, but the affiliation to A. westphalicus cannot be proven.

Stratigraphic and geographic range. - Upper Santonian (e.g. Wittler et al. 1999) to Upper Campanian of Germany (Schlüter 1876), Poland, Spain (e.g. Wilmsen 2000) and probably Hungary (Fözy 2001).

\section{Morphological and palaeoecological interpretation}

Morphological changes during ontogeny, especially of some representatives of Angulithes, are partially mentioned in their original descriptions and diagnoses (e.g. Foord 1891, Kummel 1956); however, they were interpreted only rarely. This applies also to the description of A. galea (Fritsch \& Schlönbach 1872, pp. 175, 176). The ontogenetic morphological changes of this species are most remarkable in the large specimens with diameters of 250 to $320 \mathrm{~mm}$. The last, and in several cases also the penultimate, phragmocone chamber are significantly thinner than the foregoing chambers. This septal crowding of the last phragmocone chambers is a relatively common feature of numerous species (e.g. Stenzel 1964, Wilmsen 2000). The ventral keel is predominantly developed on the last whorl, but is missing in the early stage of ontogeny, and is also gradually decreasing in height on the last whorl of a fully-grown shell, close to the apertural area. The exact position at which the keel is reduced depends on the size of the shell. The position on bigger shells is approximately at $2 / 3$ of the body chamber, and the position on the "smaller" shells is approximately at $3 / 4$ of the body chamber, closer to the aperture. Associated with the disappearance of the keel is a significant change in the whorl cross-section. The shape at first has the same height and width ratio with a strong keel on the ventral side but gradually changes into a more depressed shape with strongly convex lateral sides and a regularly rounded ventral side. The maximum width 


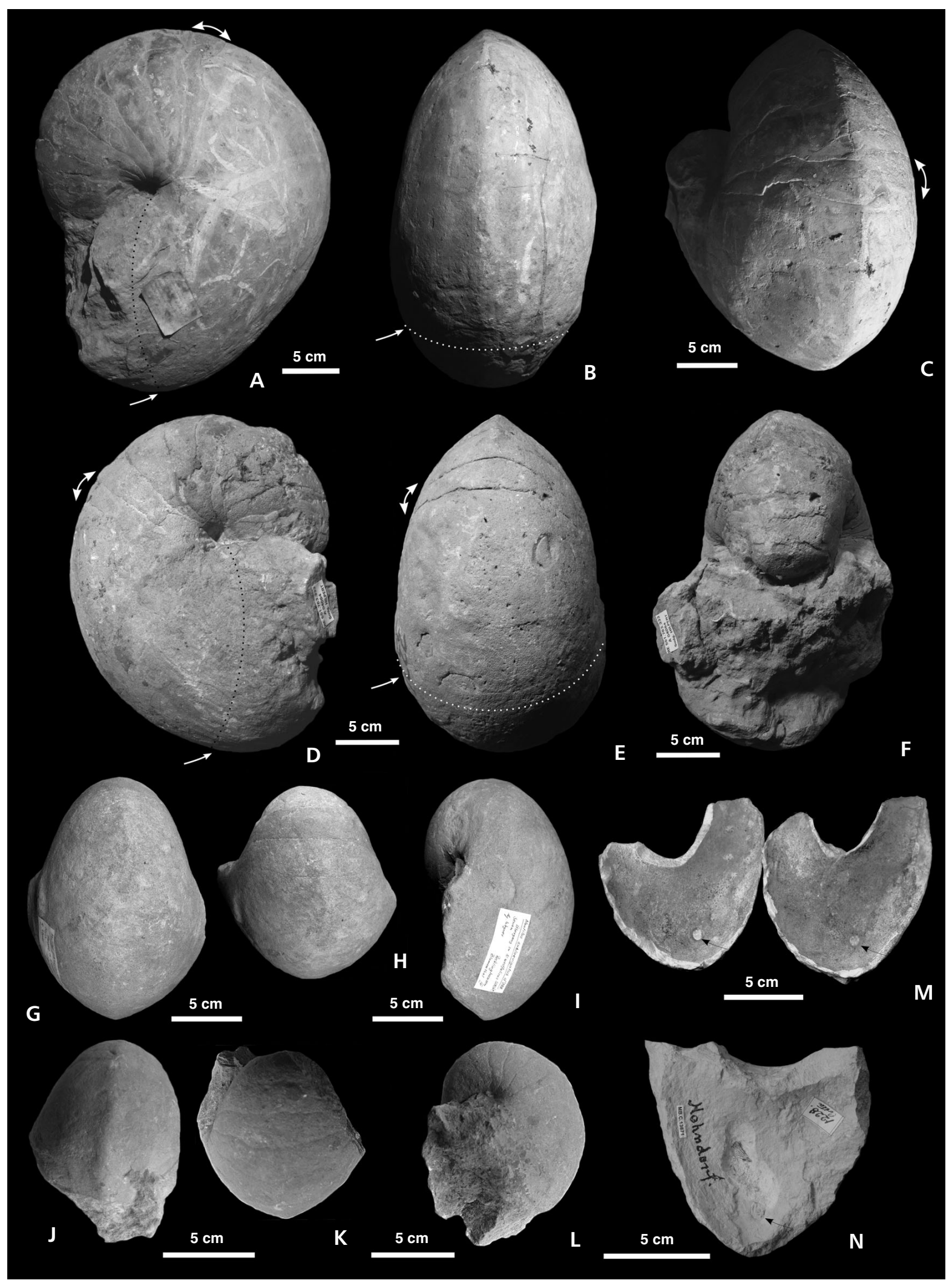

Figure 3. Adult and juvenile specimens of Angulithes westphalicus (A-I) and a juvenile specimen and phragmocone chambers of Angulithes galea $(\mathrm{J}-\mathrm{N})$. A-C - lectotype GMB 97; D-F - specimen RE 551.763.333 A 4084; G-I - specimen MB A23; J-L - specimen MT P 542; M - specimens RMT P $1325 / 1,2 ; \mathrm{N}-$ specimen MB. C. 13871 . Dotted white and black lines highlighted by arrows show the forming of the apertural contraction. White lines with arrows show the sizes of the last phragmocone chambers. Black arrows show the positions of the siphuncle. 

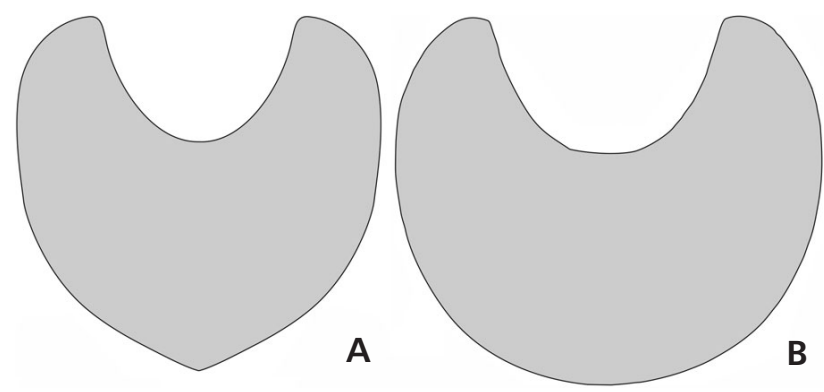

Figure 4. The whorl cross-sections of Angulithes galea. - A - whorl cross-section in the area of the living chamber with remarkable ventral keel. - B - whorl cross-section in the area of the living chamber closer to aperture where the keel is reduced (modified from Fritsch \& Schlönbach 1872).

of the whorl cross-section is on the inner lateral sides and gradually changes towards the middle of the lateral sides. The gradual decrease of the ventral keel is accompanied by a strong radial ribbing of the shell, which is otherwise completely smooth, comprising only growth lines. The ribbing partially crosses the keel and continues towards to the aperture.

The approach of maturity and attainment of maturity in recent Nautilus is indicated by several features (Stenzel 1964): white ventral area; thickened apertural edge; pronounced ocular sinuses; thickening of the final septum; rounded broadening of the fully mature body chamber; apertural contraction; change in shell coiling and increase in the length of the mature body chamber (Collins \& Ward 1987). The features which can also be recognized in fossil representatives are in this case apertural contraction, broadening of the body chamber, thickened apertural edge, and increase in body chamber length. It is possible to demonstrate all these changes in Angulithes galea. The loss of the ventral keel is interpreted as a consequence of the rounded broadening of the body chamber and subsequent apertural contraction. A fully reduced keel may mark the attainment of maturity. The broadening of the body chamber extends the whorl laterally and the ventral side becomes broadly rounded. The consequence of this morphological change is an extension of the capacity of the body chamber, probably in order to cover the larger reproductive organs in the same way as in the recent Nautilus (Collins \& Ward 1987).

The function of the ventral keel is related to hydrodynamics (e.g. Chamberlain \& Westermann 1976), providing higher stability of the shell during swimming and saving the animal energy during movement. The keel still fulfils this function even after its loss at maturity because a large part of the keel still persists on the last whorl. The absence of the keel in the early ontogeny of juvenilles is unclear and may correspond with the size of the shell.

The functional morphology of strong apertural ribbing is a topic open to debate as is the function of radial ribbing in Cymatoceratids (e.g. Chamberlain \& Westermann 1976, Tintant \& Kamamba 1985, Wilmsen \& Yazykova 2003). This study suggests several explanations for this case of ap- ertural ribbing. One solution is based on analogy with the thickened apertural edge which is a reliable indicator of a fully mature shell in recent Nautilus (Collins \& Ward 1987). The large shell with a large body chamber would be relatively fragile, especially around the aperture. The formation of strong ribbing significantly strengthens it. This strengthening may correspond to the environment where the mature specimen lives and the potential risk of shell damage, e.g. by turbulence and strong currents. The specimen could also occur in an environment with a higher potential risk for shell damage after achievement of sexual maternity in order to reproduce, but it is hard to prove and we can only discuss the possibility. Another suggestion concentrates on the stability of the shell. The strong ribbing is formed after the keel decreases and may equilibrate the shell, acting as a counterweight to stabilise it in a living position. The keel has a hydrodynamic function which is most important during swimming, and the function of the strong ribbing will, in this case be to hold the shell in a stable position. The question arises, if this function could not be also fulfilled by large reproductive organs.

The approximation of the last phragmocone chamber is a reliable indicator of approaching maturity, rather than of full maturity. It is present also on the last chamber of large immature shells and indicates that the final septa are secreted before completion of the body chamber (Collins \& Ward 1987).

Very similar morphological changes as those in Angulithes galea (onset and loss of the ventral keel and change in the ventral side of the whorl cross-section) are observed in Deltocymatoceras, D. rugatus (Fig. 5A-D) and D. leiotropis (Fig. 5E-G). However, one of the main differences is the radial ribbing which occurs over the whole shell of Deltocymatoceras. The rounded broadening of the body chamber combined with the loss of the keel and apertural contraction are very similar.

\section{Conclusions}

During the revision of Angulithes westphalicus (Schlüter 1872), the original type specimen figured in Schlüter (1876, pl. 47, figs 1, 2) was discovered in the collections of the Goldfuß Museum (Bonn, Germany). This specimen is suggested as the lectotype in this study. The revision of $A n-$ gulithes galea (Fritsch in Fritsch \& Schlönbach, 1872) designates this species as Angulithes and extends its palaeogeographic and stratigraphic occurrence. It also suggests as the lectotype the only preserved specimen from the original type collection which was discovered in the collections of the National Museum (Prague, Czech Republic). On the basis of comparison with the morphology of recent Nautilus, the remarkable morphological changes in the large specimens of $A$. galea and $A$. westphalicus are evidently an 


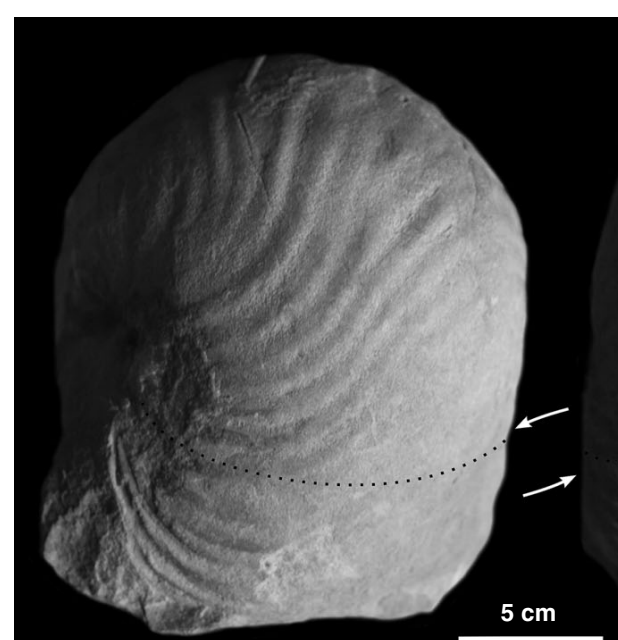

A
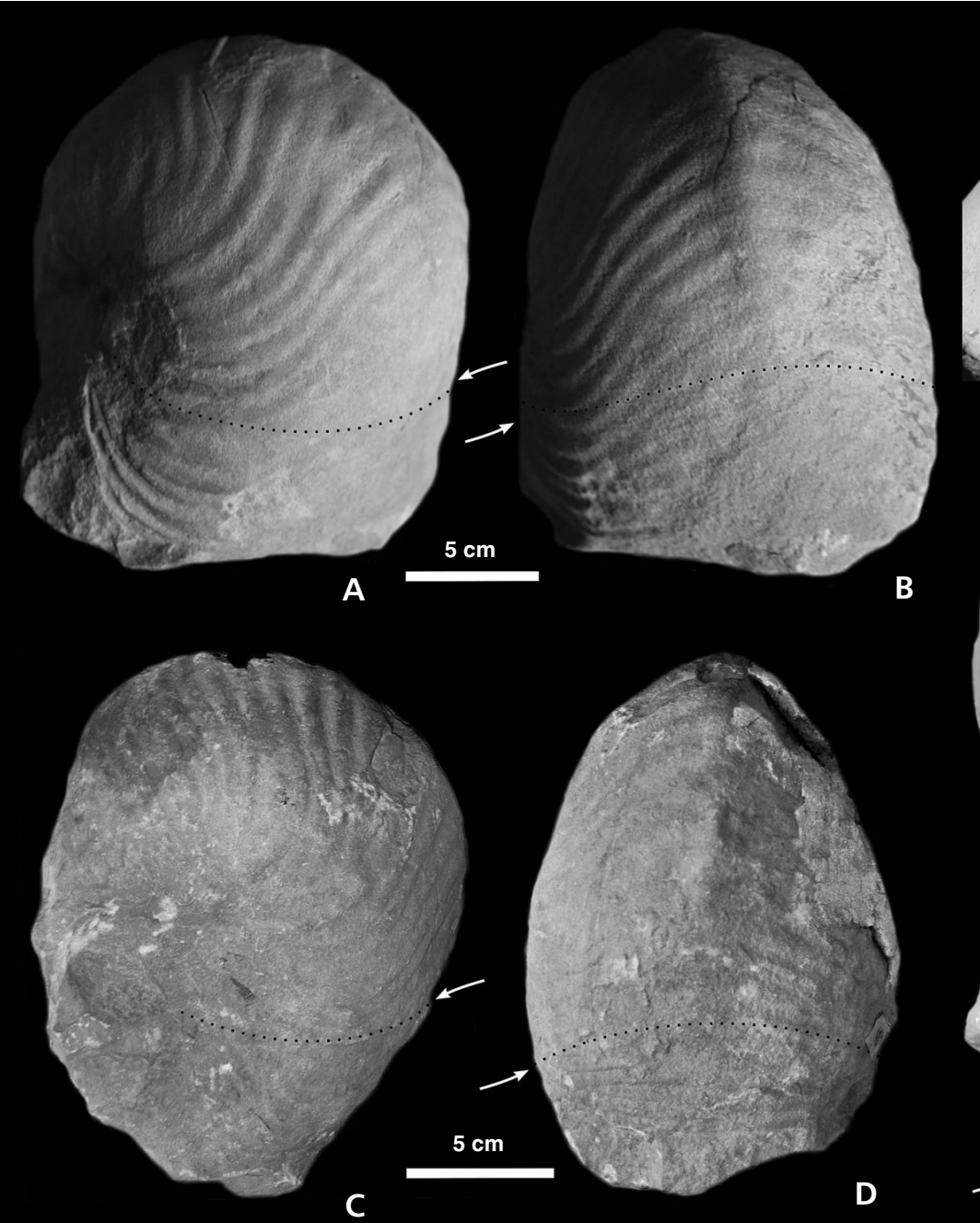

C

D
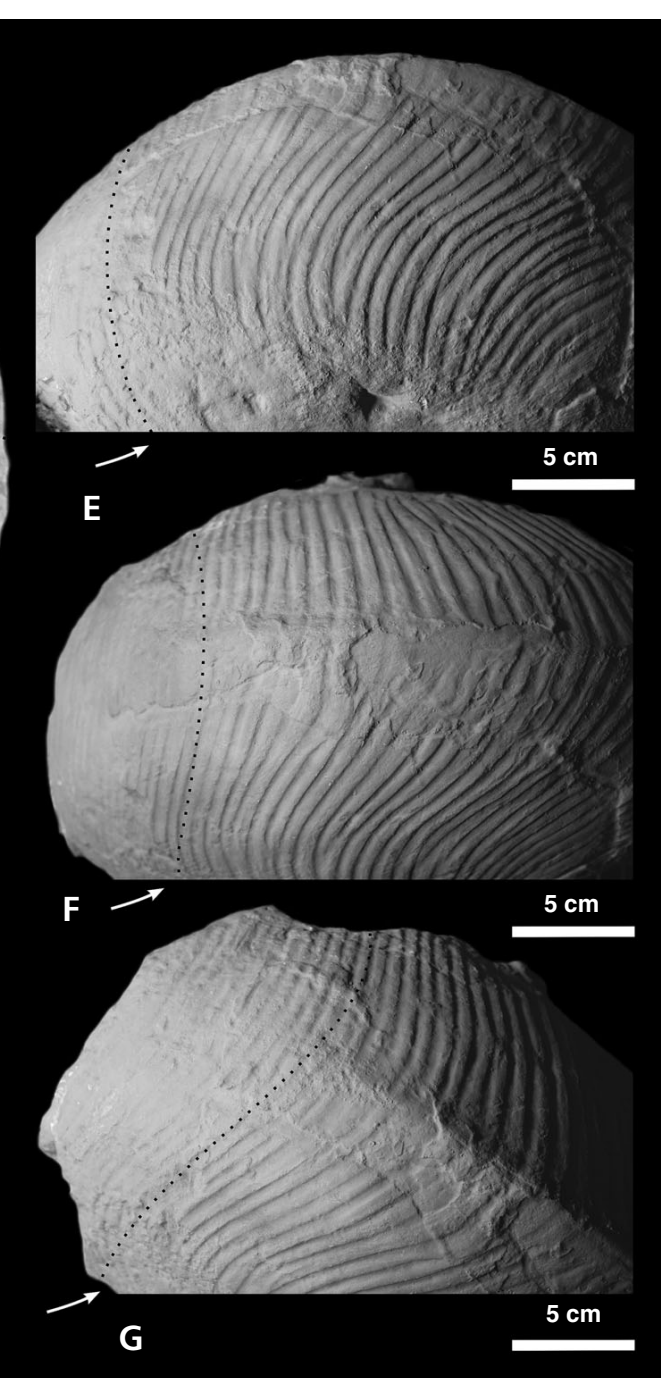

Figure 5. Adult specimens of Deltocymatoceras rugatus (A-D) and Deltocymatoceras leiotropis (E-G). • A, B - specimen NM O 06417; C, D - specimen NM O 6093; E-G - specimen MB A 24. A dotted black line highlighted by arrows shows the forming of the apertural contraction.

expression of the state of final maturity. Several solutions for the interpretation of morphological changes during ontogeny and their function are suggested. Based on new findings, it is possible to similarly interpret morphological changes at maturity in representatives of Deltocymatoc eras. Maturity in A. galea is accompanied by features such as strong radial ribbing which is unusual in Angulithes, but is comparable with ribbing of Deltocymatoceras.

\section{Acknowledgements}

I am very grateful to Jan Sklenář (NM, Prague), Udo Scheer (RM, Essen), Sandra Kaiser (GM, Bonn), Dieter Korn (MN, Berlin), Lorna Steel (NHM, London), Herbert Summesberger (NMW, Wien) and to the curators of the Czech Regional Museums for accessibility to nautilid material; Martin Košták, Jaroslav Marek (Institute of Geology and Palaeontology, Charles University, Prague) and Paul Jeffery (Oxford University Museum of Natural History, Oxford) for critical comments and very valuable information. I especially thank Paul Jeffery and Zuzka Košařová for excellent linguistic reviews; the reviewers Dan Stephen and Markus Wilmsen and the editor Štěpán Manda for their very helpful comments. This research was supported by project grant GAUK 22207.

\section{References}

Chamberlain, JR., J.A. \& Westermann, G.E.G. 1976. Hydrodynamic properties of cephalopod shell ornament. Paleobiology 2 , 316-331.

Collins, D. \& WARD, P.D. 1987. Adolescent growth and maturity in Nautilus, 421-431. In SAunders, W.B. \& LANDMAN, N.H. (eds) Nautilus: the biology and paleobiology of a living fossil. Plenum Press, New York \& London.

DzIK, J. 1984. Phylogeny of the Nautiloidea. Palaeontologia Polonica 45, 1-220.

ENGESER, T. 1999. Phylogeny of the "Post-Triassic" nautiloids. 
Fifth International Symposium Cephalopods - Present and Past (Vienna), Abstracts, 36.

Foord, A.H. 1891. Catalogue of the fossil Cephalopoda in the British Museum (Natural History), part 2, containing the remainder of the suborder Nautiloidea, constisting of the families Lituitidae, Trochoceratidae, and Nautilidae with a supplement. 407 pp. British Museum (Natural History), London.

FöZY, I. 2001. Campanian (Late Cretaceous) cephalopods from Sümeg (Transdanubian Central Range, Hungary). Fragmenta Palaeontologica Hungarica 19, 25-37.

Frank, J. 2007a. Upper Cretaceous Nautiloids of Epicontinental Seas in Central Europe - Bohemian Cretaceous Basin. Seventh International Symposium Cephalopods - Present and Past, Sapporo (Japan), Abstracts, 112-113.

Frank, J. 2007b. Nautiloidea české křídové pánve. 8. paleontologická konferencia, zborník abstraktov, 35-36.

FRANK, J. 2009. Deltocymatoceras galea (Fritsh, 1872) the remarkable Upper Cretaceous Nautilid (Cephalopoda). $10^{\text {th }}$ Anniversary Conference of the Czech, Polish and Slovak Paleontologists, Abstracts, 13-14.

FRIČ, A. 1883. Studien im Gebiete der Böhmischen Kreideformation; Palaeontologische Untersuchungen der einzelnen Schichten; III. Die Iserschichten. Archiv der naturwissenschaftlich Landesdurchforschung von Böhmen, Geologische Abteilung 5(2), 1-144.

Frič, A. 1885. Studie v oboru kř́ídového útvaru v Čechách. Paleontologické prozkoumání jednotlivých vrstev. III. Jizerské vrstvy. Archiv pro přirodovědecké prozkoumání Čech, Geologické oddělení 5(2), 1-132.

FRITSCH, A. \& SCHLÖNBACH, U. 1872. Cephalopoden der böhmischen Kreideformation. 52 pp. Prag.

GeINITZ, H.B. 1872-1875. Das Elbthalgebirge in Sachsen. Teil II: Der mittlere und obere Quader. Palaeontographica 20(II), 1-245.

Hyatt, A. 1883-1884. Genera of Fossil Cephalopods. Proceedings of the Boston Society of Natural History 22, 253-338.

KošŤ́́, M., ČECh, S., Ekrt, B., Mazuch, M., Wiese, F., Voigt, S. \& Wood, C.J. 2004. Belemnites of the Bohemian Cretaceous Basin in a global context. Acta Geologica Polonica 54(4), 511-533.

Kummel, B. 1956. Post-Triassic Nautiloid genera. Bulletin of the Museum of Comparative Zoology at Harvard College in Cambridge 114, 319-494.

Leymerie, A. 1842. Sur le terrain Crétacé du Department d'Aube. Mémoires de la Société Géologique de la France, Série 1(5), 1-56.

Matsumoto, T. 1983. Cretaceous nautiloids from Hokkaido - I. Transactions and Proceedings of the Palaeontological Society of Japan, New Series 129, 9-25.

Matsumoto, T. \& Muramoto, K. 1983. Cretaceous Nautiloids from Hokkaido - II, part 2. Three Nautiloid species from the Santonian and Campanian of Hokkaido. Transactions and Proceedings of the Palaeontological Society of Japan, New Series 130, 85-95.

MONTFORT, D. 1808. Conchyliologie systèmatique et classification méthodique des coquilles; offrant leurs figures, leur arrangement générique, leurs descriptions caractéristiques, leur noms; ainsi que leur synonymie en plusieurs langues. Conchyliologie systèmatique, Tome premiere. 409 pp. F. Schoell, Paris.

D'Orbigny, A. 1840-1842. Paléontologie Française. Terrain Crétacé I, Céphalopodes. 662 pp. Masson, Paris.

SCHLÜTER, C. 1871-1876. Cephalopoden der Oberen Deutschen Kreide. Palaeontographica, Erster und zweiter Teil. 263 pp. T. Fisher, Bonn.
SCHLÜTER, C. 1872. Die Spongitarienbänke der oberen Quadratenund unteren Mucronaten-Schichten des Münsterlandes. 20. Hauptversammlung der Deutschen Geologischen Gesellschaft, Sept. 1872.38 pp. A. Henry, Bonn.

Shimansky, V.N. 1975. Cretaceous Nautiloids. Trudy Paleontologicheskogo Instituta Akademii Nauk SSSR 150, 1-208. [in Russian]

SOWERBY, J. 1812-1822. The mineral conchology of Great Britain; or coloured figures and descriptions of those remains of testaceous animals or shells, which have been preserved at various times and depths in the earth. $266 \mathrm{pp}$. Published by the author, London.

Spath, L.F. 1927. Revision of the Jurassic cephalopod fauna of Kachh (Cutch). Memoir of the Geological Survey of India, Paleontologica Indica, New Series 9(1), 1-71.

Stenzel, H.B. 1964. Living Nautilus, K59-K93. In Moore, R.C. (ed.) Treatise on invertebrate paleontology. Part K. Mollusca 3, Cephalopoda. Geological Society of America \& University of Kansas, Lawrence \& New York.

Teichert, C. 1947. Notes on Eocene nautiloids from Victoria. Mining Geological Journal 3(1), 40-42.

Teichert, C. 1964. Morphology of hard parts, K13-K53. In Moore, R.C. (ed.) Treatise on invertebrate paleontology. Part K. Mollusca 3, Cephalopoda. Geological Society of America \& University of Kansas, Lawrence \& New York.

Tintant, H. \& Kabamba, M. 1985. The role of the environment in the Nautilaceae, 58-66. In BAyer, U. \& SeIlacher, A. (eds) Sedimentary and evolutionary cycles. Lecture Notes in Earth Sciences 1 .

WANI, R. 2004. Experimental fragmentation patterns of modern Nautilus shells and the implications for fossil cephalopod taphonomy. Lethaia 37, 113-123.

DO] $10.1080 / 00241160410006420$

WANI, R. 2007. How to recognize in situ fossil cephalopods: evidence from experiments with modern Nautilus. Lethaia 40, 305-311. DOI 10.1111/j.1502-3931.2007.00029.x

WANI, R. \& AYYASAMI, K. 2009. Ontogenetic change and intra-specific variation of shell morphology in the Cretaceous Nautiloid (Cephalopoda, Mollusca) (D'Orbigny, 1840) from the Ariyalur area, southern India. Journal of Paleontology 83(3), 365-378. DOI $10.1666 / 08-119.1$

WARD, P.D. 1980. Comparative shell shape distributions in Jurassic-Cretaceous ammonites and Jurassic-Tertiary nautiloids. Paleobiology 6, 32-43.

WiedmanN, J. 1960. Zur Systematik jungmesozoischer Nautiliden. Palaeontographica, Abteilung A 115, 144-206.

Wiedmann, J. \& Schneider, H.L. 1979. Cephalopoden und Alter der Cenoman-Transgression von Mühlheim-Broich, SWWestfalen, 645-680. In Wiedmann, J. (ed.) Aspekte der Kreide Europas. International Union of Geological Sciences, Series A 6.

Wilmsen, M. 2000. Late Cretaceous nautilids from northern Cantabria, Spain. Acta Geologica Polonica 50(1), 29-43.

Wilmsen, M. \& YazyKova, E.A. 2003. Campanian (Late Cretaceous) nautiloids from Sakhalin, Far East Russia. Acta Palaeontologica Polonica 48(3), 481-490.

Wittler, F.A., Roth, R. \& Legant, J. 1999. Die Nautiliden der oberen Kreide vom Süd- und Westrand des Münsterländer Beckens. Arbeitskreis Paläontologie Hannower 27, 1-52.

ZIEGLER, V. 2003. Stratigrafie křídových sedimenti̊ v oblasti Českého ráje. 96 pp. Faculty of Education, Charles University, Prague. 